\title{
(A)RCHITECTURE AT THE HARDWARE STORE
}

\author{
CATHY SMITH \\ School of Design \\ Queensland University of Technology \\ George St, Brisbane, QLD 4000, Australia \\ cd.smith@qut.edu.au
}

\begin{abstract}
In this paper, I explore do-it-yourself approaches in installation art and building projects. Although DIY products and systems were developed to help non-professionals, they can also enable professionals to experiment with different methods of creating buildings and spaces. DIY approaches allow people to change spaces while they occupy them, because do not require specialized construction tools, knowledge and insurance. This has practical implications for design and its practice. I show how DIY approaches create evolving, germinant spaces by looking at examples of site-specific installations and experimental residential projects. The blurring of designing, making and occupation in these projects reveals how everyday materials can act upon and transform design practice.
\end{abstract}

Keywords: DIY, site-specific installation art, experimental making, germinant practice.

\section{DIY space}

I want to broadly define an under-acknowledged area of do-it-yourself practice: how DIY thinking, materials and products help artists and architects to develop a more experimental, germinant, process-driven practice. With this in mind, I am not concerned with the aesthetic products of DIY approaches, nor the differentiation between professional and amateur practice per se, but rather how DIY can foster evolutionary design processes. DIY is largely associated with non-professional designers and amateurs. Using DIY products and materials enables relatively unskilled laypeople to create and make things with minimal or no help from professional consultants. DIY makers can circumvent the normal hierarchies associated with professional practice, particularly in terms of the commissioning and sequencing of projects. The DIY maker can act as client, designer and builder simultaneously, developing projects by blurring these normally independent roles. The non-hierarchical nature of DIY also enables professionals to work outside of their normal areas of expertise and working methods. I refer to site-specific installation and experimental residential building projects as examples of this form of DIY practice. Standard materials and DIY products enable occupants of these projects to design and develop projects through the processes of on-site construction and experimentation.

\section{DIY literature}

We have been making things for ourselves since the beginning of human history. Nevertheless, making is now a specialized, often poorly remunerated activity. How does DIY sit within 
contemporary space-making practices? There is a plethora of DIY information and products in the media, particularly on the internet, including: online zines and magazines like http://makezine.com/magazine/ and The Family Handyman; community and self-help chat rooms like http://au.groups.yahoo.com/group/DIYrenovations/ : and information websites like http://www.homesite.com.au and http://www.doityourself.com/. Hardware retailer Bunnings (2007) conducts regular weekend workshops for home renovators, with specialized activities for children and women. Product catalogues such as IKEA2007: Sort Your Life Out and Howards Storage World: a place for everything (2006) show how items can be used in residential spaces. Similarly, popular television shows like Backyard Blitz (2000-2007) present laypeople with both design ideas and practical construction advice.

Theorists attribute DIY popularity to different economic, social, technological and cultural influences. In post-war, 1950s America, DIY advertisements encouraged families to alter their homes, as part of togetherness, domesticity and post-war leisure (Sparke 1995, p. 171: Goldstein 1998, p. 37: Gelber 1999, p. 275). Paul Atkinson (2006) believes there are many motivations for DIY. For example, he refers to the DIY toy-making activities of the Victorian and Edwardian eras that developed out of economic necessity (p. 4). DIY popularity has also been affected by the increasingly array of fittings and products that can be assembled with relatively simple skills, knowledge and tools.

DIY empowers people to act without commissioning professionals. Several theorists have therefore associated DIY with democracy and democratizing processes (Lupton 2006: Atkinson 2006). In her manual for DIY graphic design, Lupton and her students encourage laypeople to appropriate design knowledge and standard technologies found in many households, such as computer graphic and printing software. Lupton believes that people are empowered when they are both designer and maker, because design products become accessible and affordable. She equates design and labor with issues of power, status and ownership (Lupton 2006, pp. 24-26: Lupton and Miller 2006).

DIY is hard to find in architectural literature, although it is often implicit in other topics related to how things are made and who makes them: these topics include self-build construction and design-by-making, as design decisions are made during the construction process. The relationship between design and making is also discussed in writings about drawing and designing. This is because drawings are often representations of how things might be constructed. Advances in drawing techniques in the fifteenth century allowed architects to design projects away from sites (Robbins 1994). Prior to this time, architects acted like a builder or contractor on site. As a consequence of the split between design and construction, architecture was associated with building ideas that were represented in drawings made in the design studio. This split also increased the social standing of the architect because construction and making were seen as inferior activities to intellectual endeavour (Robbins 1994, p. 15: Forty 2000, p. 30: Hill 2005, p. 14).

\subsection{Implications for practice}

Many contemporary theorists are interested in issues related to designing and making, due to technological changes affecting the way buildings are visualized and manufactured. This can be seen in a recent issue of the Architectural Design journal Design Through Making, in which architects look at the design implications of digitized manufacturing techniques (Calicott 2005: Ayres 2005). Exploring issues of design production reinforces the processes of architecture rather than its products alone. Some theorists use this emphasis on process to advocate a broader conception of architecture and its materials, mediums and methods (Mitchell 1993, p. 89: Hill 1998, p. 148: Hill 2005, p. 20: Willis1999, p. 107: Schulz-Dornburg 2000, p. 15).

Other theorists look at how design-by-making affects the creation of actual buildings. In the 1960s and 1970s, architect Walter Segal developed a method of self-build housing to enable occupants to design and develop their own houses to some degree. His building projects were based on a modular plan and common buildings materials that are easily manipulated on site by future building inhabitants (Hughes 2000, p. 180: McKean 1989, p. 148). The self-build housing approach has been recently described as flexible housing, which 'can adapt to the changing needs of users' (Till, Wigglesworth and Schneider 2006). Building occupants can, in theory, incorporate spatial and technological changes into their buildings over time. Similar ideas appear in the notion of unfinished buildings, Herman Hertzberger (1971) and Stewart Brand (1994) advocate for unfinished buildings, whereby building inhabitants can complete components or spaces themselves (Hertzberger 1971: Brand 1994). This approach often presumes occupants will use and / or accessible building technologies. Project home kits, 
including those designed by architects, can also be put together by or involve future residents (Arieff and Burkhart 2002, p. 51).

\subsection{The germinancy of DIY}

Regardless of the positioning of DIY in historical, social, cultural and theoretical contexts, it has practical implications for building procurement. DIY allows occupants to be involved in both making and design, often simultaneously. These activities happen as part of everyday life and building use, often resulting in evolutionary, germinant spaces. I use the term germinant because it is an adjective that means 'gradually developing' (Kellerman 1980, p. 408), and germinant buildings are always changing. I believe germinant thinking is implicitly reflected in design theories and practices that open up designing to other influences, particularly the creative input of non-designers during the construction phases.

DIY approaches are normally associated with home renovation and hobby projects rather than design through making approaches. I want to address this deficit by fist speculating on examples of DIY thinking in site-specific installation art, an area not normally associated with the DIY tradition. The more poetic term, bricolage, has appeared in art and cultural discourse. Bricolage is the French term for do-it-yourself, often used in a derogatory sense to differentiate between amateurs and professionals.

\section{Bricolage in site-specific installation art}

Bricolage stems from the French verb bricoleuer which means to fiddle and tinker (Wikipedia 2007). A bricoleur assembles things or ideas and 'then puts them together in a way that they were not originally designed to do' (Wikipedia 2007). Bricolage has also been used in art and cultural theory, associated in particular with Claude Lévi-Strauss (Roberts 1994, p. 14). For example, Attfield (2000) uses it to understand the social and cultural issues of DIY (p. 206), while Armstrong (2002) uses it to develop his new media art research.

I think the term bricolage helps us see how DIY thinking infiltrates art projects that encourage active audience spectatorship rather than passive contemplation. Site-specific installation is a practice that has been associated with creative assemblage. This is for two reasons. First, many artists create their works from ordinary and familiar materials, to encourage the audience to interact with the works. Second, the works themselves often contain elements that can be adjusted and moved. When the audience manipulates these elements, they become like the artists who initiated the works. That is, they become bricoleurs or creative assemblers.

Theorists such as Reiss (1999) believe installation art began as a genre in the 1960s and 1970s, when artists wanted to make their artworks more accessible to the audience (p. 16). Artists also opposed what they saw as the increasing commercialization of art galleries. Many believed this commercialization oppressed the critical role of art practice. The American artist Allan Kaprow made installations of everyday and junk materials as part of his critical view of art practice (Haywood 1999, p. 37). His works were assembled from materials like rolls of paper, pens, record players, and old car tires. Kaprow made works occupy entire spaces, in the hope that they were harder to buy and consume (Reiss 1999). The audience also engaged in acts of assemblage inside Kaprow's installations, altering and reassembling the constituent materials and elements.

Two issues of bricolage implicit in site-specific installation - the artwork as everyday material assemblage and the audient as bricoleur - can be seen in several works in the recent kids' APT, part of The $5^{\text {th }}$ Asia-Pacific Triennial of Contemporary Art, in Brisbane (December2006-May 2007). Many of these works in this exhibition require the audience to do something to or in the space. In several artworks, children (and adults) assemble and reassemble parts of the artwork made of the kinds of materials used to manufacture toys. In Kwon Ki-Soo's installation Run, run, run, children create people from foam-cutouts and place them on display.

Other artworks require participants to make their own art inside the installation space. In Sutee Kunavichayanont's Classroom Upside Down, children create their own artworks by making crayon rubbings of the etched desks in the space. In another installation, Yang Zhenzhong's Light and Easy (Brisbane), the audience can take and email a trick photo of them holding a council bus in. In Tuyoshi Ozawa's Everyone Likes Someone as You Like Someone, children deliver their drawings into a mailbox atop a mountain of standard domestic futon cushions. It is refreshing to see white galleries filled with jumping and lively children, even if their exertions are limited by concerned gallery attendants and parents. 
The everyday, familiar materials used in the above installations - building blocks, foam dolls, pens and paper, computers - invite touch and appropriation because they have been taken from everyday life. The physical installations are also set up like classrooms and playgroups rather than a conventional pictorial gallery. The gallery inhabitants, the children (and their adult supervisors), make decisions about how parts of the spaces are arranged and made, therefore contributing to their aesthetic qualities. In many artworks, the children make only minimal changes to the physical spaces. For example, they take their drawings with them, or their work is displayed temporarily. Nevertheless, both the artists and audience can act as bricoleurs, creating works from materials otherwise destined for very different contexts.

\subsection{Difference in DIY intent}

I would argue there is a significant difference between placing DIY objects like readymades in an art context, using DIY materials to create a design and deploying DIY as a method of audience interaction. For example, artist Allan Wexler makes installations from standardized elements, materials and off-the-shelf products like garden sheds, and has therefore been associated with the DIY movement (Schultz 1998, p. 6). He often develops projects through a design-by-making approach. Other than manipulating some moveable elements, Wexler's projects are arguably physically finished when experienced by the audience. This is different to other installations, where it is not only the artist but the audience who can physically touch and change the works once installed on site. I would describe the latter use of DIY germinant. This reinforces that there are significant differences in the basic philosophical thinking underpinning DIY practices.

\section{The bricoleur at home}

Although DIY approaches are traditionally associated with home renovators, some DIY environments are so unique that theorists consider them seminal artworks or buildings: for example, Watts Tower in Los Angeles or The Owl House in South Africa. Their makers are usually untrained, driven by a desire to create spaces rather than to make a public artwork per se. They often work with limited means, experimenting with recycled and junk materials. Experimental making can also be seen in projects initiated by professionals in non-professional contexts. The houses of practicing artists and architects often act as experimental studios for testing ideas and living arrangements. Even if these artists and architects involved in these projects are professionally trained, the way they make their home projects may be very different to professional practice because of the blurring of designing, making and use on site.

Selvalegre is the Australian home of an artist and architect who work in a germinant manner. They have spent years collecting interesting objects and salvaging discarded items from construction bins around the world, which are incorporated into the fabric of their current home. Other items sit on custom-built plinths and shelves incorporated into internal walls. These quirky installations create a unique home in an otherwise standard timber-framed Queensland house. Yet I would argue it is not the physical building per se that makes it unique but rather the method of its evolution. Many changes and additions occur within the existing building footprint. This allows the occupants to construct the work themselves and work spontaneously without violating local planning and building regulations.

\subsection{Hotrod house}

DIY advocates believe that standard, readily available materials and approaches can be used in inventive and thought-provoking ways (McKean 1989, p. 148: Lupton 2006, p. 25). Although Steven Gelber (1999) differentiates between the creative and utilitarian aspects of DIY, he still acknowledges its overall creative benefits (pp. 269-270). Adapting standardized houses helps residents to personalize and transform houses into homes (Attfield 2000, p. 188). Selvalegre's resident architect believes personalization is a key issue of DIY approaches, pointing to a similar culture in the creation of hot rod vehicles. He argues that drivers create unique cars for themselves using accessible technologies from the local auto shop in the same way that home owners develop homes by using standard hardware products and details in inventive ways: for example, by customizing mass-produced IKEA kitchen fittings are customized with purpose-built doors, fittings and finishes. Many if not all houses are, to some degree, hotted up. Some transform this DIY practice into a way of life due to necessity, lifestyle choice or a combination of factors (Atkinson 2006, p. 3).

The approach used at Selvealegre resonates with aspects of a seminal architectural project, the Eames House, by Charles and Ray Eames in California. The project was officially known as the 
Case Study \#8, because it was part of a programme of experimental, postwar housing. The Eames' treated the house itself as an experimental laboratory, an ongoing project of experimental living and working, and in this sense the project embodies germinant qualities. Charles and Ray were also notable for their investigation and exploitation of new manufacturing technology and materials: showing how modern, mass-produced technologies are readily appropriated in uniquely crafted projects. However, the Eames house also evolved slightly differently to Selvalegre, because of changes to built-in elements. Even if furnishing, interior partitions and object display changed regularly, the basic spatial configuration as defined by the structure was worked out in advance to construction (Colomina 1997, p. 133): this can be seen in the 1949 plan published in Arts \& Architecture. In contrast, Selvalgre's floor plan changes such an outdoor bathroom, a garage reconstruction and a new kitchen - developed individually and somewhat spontaneously over time rather than according to an overarching vision for a set plan area.

I believe the Eames' germinant, DIY thinking is more obvious in their approach to interior design and decoration, and furniture and object design. They used the term "functioning decoration" (Kirkham 1998, p. 192) to describe the changing display of personal and inspirational objects, and they designed changeable interior fittings to encourage other people to engage in this activity. Their pegboard wall system for screenwriter's Philip Dunne's 1952 office fitout accommodated changing display elements (Kirkham 1998, p. 193). They also designed toys, such as The Toy (1951) and House of Cards (1952) that could be assembled and reassembled into different configurations. These latter projects embody the do-it-yourself attitude to creating form seen in contemporary installation projects, particularly those tapping into the energies of children! Toys encourage an uninhibited approach to life, which, according to the Eames', was perfect for exploring design problems (Colomina 1997, p. 139).

\section{DIY as germinant practice}

DIY does raise issues related to safety and wellbeing. While in some cases, DIY can increase personal safety issues related to poor workmanship (Gelber 1999, p. 275), it can also be selfactualizing (McKean 1989, p. 174: Cross 1996, p. 83: Gelber 1999, p. 292: Lupton 2006, p. 21: Atkinson 2006, p. 7). However, many regulatory bodies remain unconvinced, particularly when poor workmanship leads to injury. In a 2000 case in Brisbane, a deck collapsed, injuring fifteen people. This case and similar incidents prompted the Queensland State Government to issue warnings against DIY activity during the 2004 Easter period in a Brisbane weekend newspaper (Giles and Robson 2004). In the 1950s, authorities encountered the same safety concerns during the DIY boom. Rather than discourage DIY altogether, they highlighted the dangers of undertaking structural repairs. Instead, they encouraged home renovators to tackle only 'small repairs, cosmetic improvements, and light construction projects' (Gelber 1999, p. 275).

DIY projects can involve a degree of on-site material experimentation that may increase maintenance issues. I witnessed this when the domestic futons used in Ozawa's APT installation required replacement in March 2007. Nevertheless, devoting time and energy to DIY projects can be personally, socially or culturally empowering. In this context, DIY approaches contribute to alternative design practices. DIY enables artists, designers and audiences without professional construction skills to design by making, even if their projects are limited in scope. Projects develop in unpredictable and exciting directions that could not be imagined in design drawings alone. Spaces develop in and through their materials, transforming an apparently quotidian visit to the local hardware store into an inventive, creative act.

\section{References}

Arieff, Allison and Bryan Burkhart. Prefab. Salt Lake City: Gibbs Smith, Publisher, 2002.

Armstrong, Keith. Towards an ecosophical praxis of new media space design. Ph.D. Diss. Creative Industries Research and Applications Centre. Brisbane: Queensland University of Technology, 2002.

Atkinson, Paul. (2006). "Do It Yourself: Democracy and Design". Journal of Design History. 19. 1 (2006). 30 Mar. 2007 < http://jdh.oxford.journals.org/cgi/reprint/19/1/1>

Attfield, Judy. Wild Things: The Material Culture of Everyday Life. Oxford: Berg, 2000.

Ayres, Phil. (2005). "Getting Specific". Design Through Making. Architectural Design. Ed. Bob Sheil. Chichester: Wiley-Academy. 75. 4 (2005): 58-65. 
Backyard Blitz. Home page. 2000. CTC Productions. 4 April 2007. $<$ www.burkesbackyardblitz.com>.

Brand, Stewart. How Buildings Learn: What Happens After They're Built. New York: Penguin Books Ltd., 1994.

Bunnings. Ladies D.I.Y. Nights. 2007. Bunnings Group Limited. 4 April 2007. $<$ http://www.bunnings.com.au/diy/diyworkshopladies.aspx>

Callicott, Nick. "Adaptive Architectural Design". Design Through Making, Architectural Design. Ed. Bob Sheil. Chichester, Wiley-Academy. 75. 4 (2005): 66-69.

Colomina, Beatriz. "Reflections on the Eames House". The Work of Charles and Ray Eames: A Legacy of Invention. Ed. Diana Murphy. New York: Harry N. Abrams, Inc., 1997. 126-149.

Cross, Rosie. "GEEKGIRL: Why grrrls need modems." DIY Feminism. Ed Kathy Bail. Sydney: Allen \& Unwin Pty Ltd, 1996. 77-86.

DoltYourself.com. How-To Info. 1995. INTERNET BRANDS company 4 April 2007. $<$ http://www. doityourself.com>.

Forty, Adrian. Words and Buildings: A Vocabulary of Modern Architecture. New York: Thames and Hudson, 2000.

Gelber, Steven M. Hobbies: Leisure and the Culture of Work in America. New York: Columbia University Press, 1999.

Giles, Darrell and Lou Robson. "Warning: Don't try doing this at home". The Sunday Mail. Brisbane. 4 April 2004: sec 1: $1+$.

Goldstein, Caroline M. DO IT YOURSELF: Home Improvement in 20th-Century America. New York: Princeton Architectural Press, National Building Museum, Washington, D.C., 1998.

Haywood, Robert. "Critique of Instrumental Labor: Meyer Schapiro's and Allan Kaprow's Theory of Avant-Garde Art." Experiments in the Everyday: Allan Kaprow and Robert Watts - Events, Objects, Documents. Ed. Benjamin H. D. Buchloh and Judith F. Rodenbeck. New York: Miriam and Ira D. Wallach Art Gallery, Columbia University in the City of New York, 1999. 2746.

Hertzberger, Herman. "Looking for the beach under the pavement". Royal Institute of British Architects Journal, 78. August (1971). 328-333.

Hill, Jonathan. "An Other Architect." Occupying Architecture. Ed. Jonathan Hill. London: Routledge, 1998.135-159.

Hill, Jonathan. Building the Drawing. Design Through Making. Architectural Design. Ed. Bob Sheil. Chichester: Wiley-Academy. 75.4 (2005): 13-21.

homesite.com.au. HOW TO channel. 2007. NL/HIA JV Pty Ltd.. 4 April 2007. $<$ http://www.homesite.com.au/how-to-channel/9?247SEO=N>

Howards Storage World. a place for everything. Sydney: Howards Storage World Pty. Ltd., 2006.

IKEA. IKEA 2007: Sort Your Life Out. IKEA Australia, 2006-2007.

Kellerman, Dana et al, ed. The Lexicon Webster Dictionary. USA: Delair Publishing Company, Inc., 1980.

Kirkham, Pat. Charles and Ray Eames: Designers of the Twentieth Century. Cambridge: The MIT Press, 1998.

Lupton, Ellen, ed. D.I.Y. Design It Yourself. New York: Princeton Architectural Press, 2006.

Lupton, Ellen and J. Abbott Miller. "Streamlining: The Aesthetics of Waste." Intimus: Interior design Theory Reader. Ed. Mark Taylor and Julieanna Preston. West Sussex: John Wiley and Sons Ltd., 2006. 204-212.

makezine.com. Make Magazine. 2005. Dale Dougherty, O'Reilly Media, Inc..4 April 2007. $<$ http://makezine.com/magazine>

McKean, John. Learning From Segal: Segal's Life, Work and Influence. Basel: Birkhäuser Verlag, 1989. 
Mitchell, C. Thomas. Redefining Designing: From Form to Experience. New York: Van Nostrand Reinhold, 1993.

Reiss, Julie. From Margin to Centre: The Spaces of Installation Art. Cambridge: The MIT Press, 1999.

Robbins, Edward. Why Architects Draw. Cambridge: The MIT Press, 1994.

Schulz-Dornburg, Julia. Art and architecture: new affinities. Barcelona: Editorial Gustavo Gili, 2000.

Sparke, Penny. As Long As It's Pink. London: Pandora, 1995.

Schulz, Bernd. "Introduction". allan wexler. Barcelona: Editorial Gustavo Gili, 1998.

Till, Jeremy, Sarah Wigglesworth and Tatjana Schneider. Flexible Housing Project. 2006. Sheffield: Sheffield School of Architecture. 4 March 2007. < $\underline{w w w . f l e x i b l e h o u s i n g . o r g>~}$

Wikipedia encyclopedia. Bricolage. 2007. Wikimedia Foundation, Inc.. 4 April 2007. $<$ http://en.wikipedia.org/wiki/Bricolage>. 